\title{
On the Problem of Implicitness in Metaphoric Similes
}

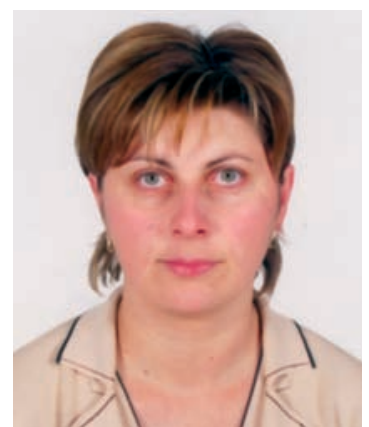

Gohar Haroutunian

T anguage, which is the instrument of logic and discourse standing between man and expression, influences and determines the way its speakers understand the world around them. Linguistic communication is easily accomplished, but not so easily explained. Its serious investigation is an exciting, enjoyable experience leading to a better understanding of ourselves as well as the world as a whole. The correlation 'speaker - sign' has aroused considerable interest recently. This is conditioned by the fact that the role of man is regarded as central in the process of communication. When we focus on the function of language, we focus on what a person is doing with words in particular speech situations. Namely, we focus on the speaker's intentions, purposes, beliefs, etc. Therefore, the speaker's communicative intention is an inseparable part of the message communicated. It has generally been acknowledged that the meaning of a particular linguistic expression is governed by rules of syntax, semantics, phonology and style, but the choice of that particular type is strongly affected by the pragmatic purpose of the utterance. Pragmalinguistic analysis has proved to be very effective when applied to implicit aspects of language use. It is of special interest when both the speaker (author) and the listener (reader) go beyond what is conveyed by the language form itself or what is literally said. Metaphoric similes viewed from this point of view are of particular interest. The linguistic phenomenon of simile and its relation to other classical tropes and figures of speech has certainly been the focus of much thought. This article is to show the need for a pragmatic approach to similes and to sketch the directions in which such a pragmatic account might contribute to the study of them.

The choice of the subject matter of the present investigation is conditioned by the fact that metaphoric similes are characterized by a higher degree of implicitness in which case the associations leading to assimilation may seem complicated and rather incomprehensible at first sight. The complex correlation between a word, the thing it denotes and the image created entails a complete scale of subtle shades of meaning. This gives rise to various implicatures and makes the listener draw more complex inferences.

e.g. She seemed to him to teach the lamps to burn more brightly, and her beauty showed by night like a rich jewel worn by a black man.

(Shakespeare, Romeo and Juliet)

At first sight it may seem difficult to find a point of resemblance between the concepts of "beauty" and "jewel" - an abstract notion and a concrete thing. Thus, the gap between what is on the surface and what is conveyed is so substantial that a semantic 
theory cannot go beyond interpretation of literal meaning. Meanwhile, pragmatics, which relies on elements of context, provides metaphorical interpretation of wordmeaning. In the given example the comparison is made on the basis that the beauty of the heroine is as vivid at night as a rich jewel worn by a black man. How does the hearer (reader) recognize the speaker's (writer's) communicative intention when the implicit aspects of language are in use, when we mean more than what we say? In other words, very often the speaker-meaning (what we mean to communicate) is not compatible with the sentence-meaning (what our expression literally means) but is dependent on it (Grice, 1975:53-59). Common cases of this are metaphors, similes, ironies and other implicit means of language use.

\section{e.g. "Rumours are like infections."}

(D. du Mourier, Rebecca)

This utterance cannot be taken literally (or to put it in another way, it is literally false). When analyzed on the semantic level (where the nominative meanings of linguistic units are defined), the words "rumour" and "infection" have nothing in common. "Rumour" means "general talk, gossip, statement which cannot be verified and is of doubtful accuracy". "Infection" has the meaning of "disease which can be spread from person to person, especially through the air". Thus, the interpretation of so-called literal meaning is far from what the speaker intends to convey. The comparison is carried out and adequately comprehended because of the consideration that both rumour and infection are dangerous and spread rapidly. Thus, the common features mentioned here are implicit. The whole utterance may be paraphrased as follows: "Rumours like infections, spread at a fantastic speed and are dangerous, so one should avoid them."

According to Grice's theory of conversational implicature, implicit utterances are cases of maxim exploitation (Grice, 1968:64). Grice singles out different cases of breaking the maxims. For example, if the speaker breaks the maxims secretly by telling a lie, he is "violating the maxim". Accordingly, if he breaks them deliberately, he is "flouting the maxim". From the linguistic point of view, the cases of flouting are more interesting as they give rise to various implicatures depending on the context and the speaker's communicative intention. Metaphoric similes are viewed as cases of flouting the maxim of quality (the need to be truthful). However, it should be mentioned that the flouting is to be observed only on the surface level. If the listener interprets the utterance as literally untrue, or nonsensical, the cooperative principle and the maxims may lead him to search for a further deeper level of meaning, i.e. figurative meaning which to some extent preserves the maxim of quality.

e.g. Her whole mind was a chaos, darkness breaking in upon it, and herself struggling to gain control with her will, as a swimmer struggles with the swirling water.

(D.H. Lawrence, Women in Love)

In this example there is no relation of explicit similarity between the notions "mind" and "chaos". How does the listener (reader) understand that the speaker (author) implies somewhat different from what is actually said. The inference strategy involved 
in working out the speaker's message can be formulated in the form of the following steps:

1. In saying that "Her whole mind was a chaos" the speaker seems to observe the maxims (i.e. we assume that what he says is true and relevant), at least at first glance.

2. But the speaker's utterance is, nevertheless, inadequate and it does not seem to be true ("mind" and "chaos" have nothing in common).

3. This means that the speaker's utterance has some hidden, implicit illocutionary point or aim.

4. In such a situation we look for a meaning that seems to be more relevant. In general, "chaos" symbolizes disorder, mess, disharmony and darkness. Therefore, we conclude that the heroine's mind being compared to chaos expresses her disorganized state of mind - being at a loss, not knowing what to do, or how to act. Everything inside her is mixed up and she tries hard to overcome this attack of emotions.

5. Hence, the encoder aims at making his/her utterance more expressive and draws a similarity between "mind" and "chaos".

It should be pointed out that no one will consciously go through this process of inference to understand what the speaker intends to convey. People are generally not aware of doing it either as encoders or decoders. It is here that the general principles of conversation together with mutually shared background knowledge, global vertical context come to help. These factors play an important role in the speaker's creating of implicature and in the listener's interpretation of it. Only in this case the implicature that is conveyed and the one that is inferred will be essentially the same. Undoubtedly, context plays a great role in determining the indirect force of the utterance. For instance, it is held that the word "dog" may evoke various associations, namely: being dirty, sleepy, as well as prudent, devoted, etc. Often in actual speech situations context makes it clear what the utterance implies. However, the following questions are bound to arise: What facts determine indirect ways of expression? Why does the author express himself implicitly? Why is it preferable for him to say "He was no gentle lamb" instead of saying "He was obstinate, bold, shrewd, etc.", which would be more easy to perceive. The main reason is that the speaker (author) aims at making his speech more expressive, emotional in order to achieve certain aesthetic impact on the listener (reader). His intention is assumed to be fulfilled if he succeeds in getting the hearer to understand and interpret the utterance non-literally.

In the process of communication we often come across cases when the listener fails to perceive the intention of the speaker's utterance, and this gives rise to curious situations.

e.g. Do you know what time it is?

"Yes". (without any further action)

Here the speaker's intention is not achieved as the listener has failed to perceive the indirect meaning of the speaker's utterance and his answer "yes" refers only to its literal 
meaning. Thus, the listener's recognition of the speaker's communicative intention (which J. Austin terms "illocutionary uptake") is very important for any communication to be successful. In the case of metaphoric similes the listener (reader) is more free in his/her interpretation.

\section{e.g. She had eyes like forest pools.}

(S. Maugham, Salvatore)

In this example the heroine's eyes are compared to forest pools and create an image of dark eyes with a shining surface sparkling like pools and reflecting everything around like a mirror. They are framed by long eyelashes as forest trees frame forest pools. This utterance is not easily perceived and interpreted as it may create different images depending on the listener's power of imagination and ability to employ analogy. And we may assume that irrespective of the way utterances of this type are perceived and interpreted, if they arouse emotions in the listener (reader), creating certain images in the latter's mind, then the speaker's (author's) intention may be considered to be achieved i.e. he succeeds in bringing about the perlocutionary effect of aesthetic impact on the listener.

Our analysis proves once again that the meanings of words are vague in general and they may acquire some additional expressive-emotional-aesthetic overtones due to collocational environments. On the pragmatic level our task is to reveal those implicit meanings (or various connotations) that words may acquire when used in combination with other words and to explain the inferential mechanisms involved in understanding them, including their aesthetic evaluation. Metaphoric similes, due to their power of effecting energy in communication, play a significant role in the creation of a piece of verbal art. Its multifunctional character is accounted for by the fact that we, humans, like to play with words. We take ideas, give them wings and they fly like brightly coloured birds making the world around us seem more exciting and magic.

\section{References:}

1. Austin J.L. How to Do Things with Words. Oxford: Clarendon Press, 1962, p.6-29.

2. Grice H.P. Utterer's Meaning, Sentence-Meaning, and Word-Meaning. // Foundations of Language, 1968.

3. Grice H.P. Logic and Conversation. // Syntax and Semantics. Vol. 3, ed. by P. Cole and J.L. Morgan. N.Y.: Academic Press, 1975, p. 45-134.

4. Leech G.N. Principles of Pragmatics. London - N.Y.: Longman, 1983.

5. Levinson S.C. Pragmatics. Cambridge: Cambridge University Press, 1983.

6. Verschueren J. Understanding Pragmatics. N.Y.: Oxford University Press, 1999.

7. Uitti K.D. Linguistics and Literary Theory. N.Y., 1969.

8. Арутюнова Н.Д., Падучева Е.В. Истоки, провлемы и категории прагматики. // Новое в заруьежной лингвистике, вып.16. Лингвистическая прагматика. М.: Прогресс, 1985. 
9. Арутюнова Н.Д. Предложение и его смысл. Москва, 1976.

10. Гаспарян С.К. Фигура сравнения в функциональном освещении. Ереван: Изд. Ереванского университета, 2000.

11. Левин С. Прагматическое отклонение высказывания. // Теория метафоры. / Под ред. Н.Д. Арутюновой, М.А. Журинской. М.: Прогресс, 1990.

12. Серль Дж.Р. Метафора. // Теория метафоры. / Под ред. Н.Д. Арутюновой, М.А. Журинской. М.: Прогресс, 1990.

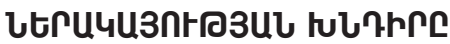 ๆusutru4nก zuUtuUsกrค3กrlutrntu}

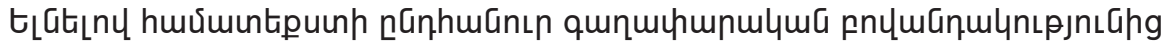

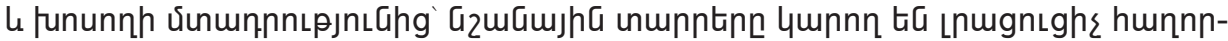

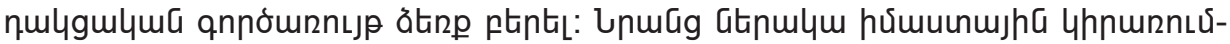

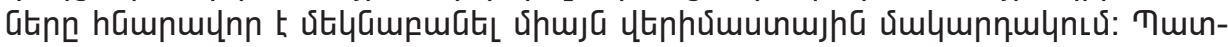

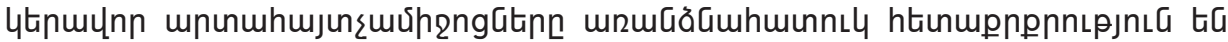

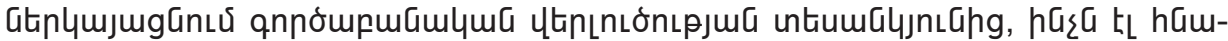

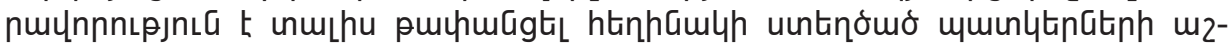

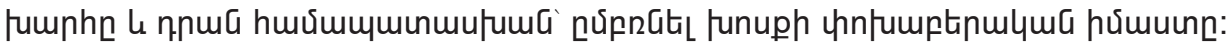

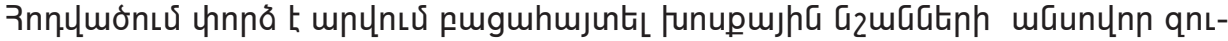

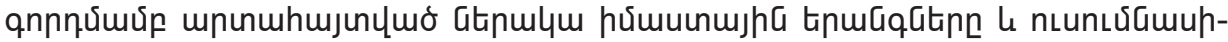

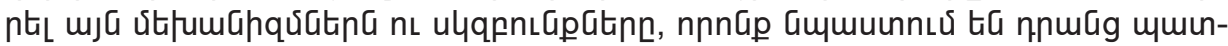

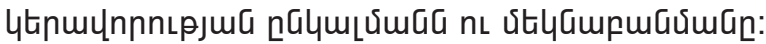

